\title{
Arbuscular mycorrhizal symbiosis and ecosystem processes: Prospects for future research in tropical soils
}

\author{
Geofrey Soka ${ }^{1^{*}}$, Mark Ritchie $^{2}$ \\ ${ }^{1}$ Department of Wildlife Management, Sokoine University of Agriculture, Morogoro, Tanzania; \\ *Corresponding Author: gesoka@syr.edu \\ ${ }^{2}$ Department of Biology, Syracuse University, Syracuse, USA
}

Received 24 November 2013; revised 24 December 2013; accepted 2 January 2014

Copyright (C) 2014 Geofrey Soka, Mark Ritchie. This is an open access article distributed under the Creative Commons Attribution License, which permits unrestricted use, distribution, and reproduction in any medium, provided the original work is properly cited. In accordance of the Creative Commons Attribution License all Copyrights (c) 2014 are reserved for SCIRP and the owner of the intellectual property Geofrey Soka, Mark Ritchie. All Copyright (c) 2014 are guarded by law and by SCIRP as a guardian.

\section{ABSTRACT}

Arbuscular mycorrhizal fungi (AMF) are more widely distributed and can associate with a wide range of plant species. AMF are keystone organisms that form an interface between soils and plant roots. They are also sensitive to environmental changes. AMF are important microbial symbioses for plants under conditions of P-limitation. The AMF are crucial for the functioning of terrestrial ecosystems as they form symbiotic interactions with plants. Mycorrhizal fungi are known to influence plant diversity patterns in a variety of ecosystems globally. AMF hyphae form an extensive network in the soil. The length is a common parameter used to quantifying fungal hyphae. The mycelial network of $A M$ fungi extends into the soil volume and greatly increases the surface area for the uptake of immobile nutrients. Also, AM symbioses improve plants tolerance to drought and enhance plants' tolerance of or resistance to root pathogens. Also, the networks of AM hyphae play a crucial role in the formation of stable soil aggregates and in the building up of a macroporous structure of soil that allows penetration of water and air and thereby prevents erosion. The functioning of AMF symbiosis is mediated by direct and indirect effects of biotic and abiotic factors of the surrounding rhizosphere, the community, and the ecosystem. AMF have great potential in the restoration of disturbed land and low fertility soil. However, despite the importance of AMF to terrestrial ecosystems, little is known about the effects of environmental changes on AMF abundance, activity and the impact of these changes on the ecosystem services. Therefore, it is important to gain a clearer understanding of the effects of environmental changes on the AM fungal species to guide conservation and restoration efforts.

\section{KEYWORDS}

Arbuscular; Mycorrhizal; Symbiosis; Hyphae; Soil; Tropical; Ecosystem

\section{INTRODUCTION}

Arbuscular mycorrhiza is the most ancient and widespread type of mycorrhiza [1]. Paleobotanical and molecular sequence data suggest that the first land plants formed associations with Glomalean fungi from the Glomeromycota about 460 million years ago [2]. This is estimated to be about 400 million years before the appearance of root nodule symbioses with nitrogen-fixing bacteria. Arbuscular mycorrhizal (AM) symbioses can be formed with as many plant species as 250,000 [1]. Only 150 - 200 species of AM fungi have so far been distinguished on the basis of morphology. However, DNAbased studies suggest that the true diversity of these symbionts may be much higher [3,4]. The symbiosis is characterized by highly branched fungal structures, arbuscules, which grow intracellularly without penetrating the host plasmalemma [5].

AMF are more widely distributed than other types of mycorrhizal associations [1]. They are keystone organisms that form an interface between soils and plant roots; and they are also sensitive to changes in soil and plant conditions [6]. They can associate with a wide range of 
plant species [7] and can infect most species of flowering plants in most habitats [8]. AMF are important microbial symbioses for plants; and under conditions of P-limitation and AMF are significant in the maintenance of soil health and fertility, plant community development, nutrient uptake and above the ground productivity [9]. For example, a study by Borowicz [10] demonstrates that plants generally grow better when they are mycorrhizal. van der Heijden et al. [11] found out that plant biodiversity, nutrient capture, and productivity in macrocosms increase significantly with an increase of AM hyphal length and AMF species richness. Plants acquire nutrients and water through mycorrhizal symbioses [5]. Numerous studies indicate that mycorrhizal symbiosis is the most important to plants where there is a deficiency of soil nutrients [12,13]. Plants exchange carbon (C) for fungal phosphorus $(\mathrm{P})$ and nitrogen $(\mathrm{N})$ [14]. AM fungi release signals molecules, which trigger a series of symbiotic plant genes; this activity prepares the intracellular root environment for colonization and arbuscules formation inside the root cortex $[15,16]$. Studies have been undertaken on the distribution and diversity of AMF species in relation to individual plant species and plant communities in farming systems $[17,18]$; and recently, there is emerging interest in the role of mycorrhizae in ecosystem processes $[18,19]$. However, only a few studies have been undertaken to track individual fungi overtime as a result of environments changes. Yet, these kinds of studies are necessary in the understanding of the dynamics of mycorrhizal symbioses.

\section{AMF FUNCTIONING AND THE ECOSYSTEM SERVICES}

AMF are crucial for the functioning of terrestrial ecosystems; and they form symbiotic interactions with terrestrial plants and colonize more than $80 \%$ of plant roots [5]. Mycorrhizal fungi are known to influence plant diversity patterns in a variety of ecosystems globally [20]. However, despite the importance of AMF to terrestrial ecosystems, the contribution of mycorrhizal fungi to the maintenance of plant diversity in the tropics is not well known [21]. It is well recognized that humans keep on changing the global environments at an unprecedented rate. These changes are known to have an impact on global climate and biota; however, the implications of these changes to communities and ecosystems are not known [22]. Understanding of the mycorrhizal responses to anthropogenic environmental changes can therefore help to predict the trajectories of future communities and ecosystems in a changing world $[19,23]$. Limited work has been undertaken in AMF at a landscape level in relation to land use changes in the tropics. However, with an increase in the interference of landscape by human beings, it is vital to establish how land use changes influ- ence AMF abundance, activity and their impact on ecosystem services. The loss of propagules of AMF may result into a decrease in the capacity of plants to take up nutrients, lowering soil fertility thus threatening the stability of the ecosystem [24]. There are a number of situations where management of the mycorrhizal symbiosis is necessary in restoring plant cover, improving plant health or increasing plant productivity.

Studies carried out in agricultural systems both in the tropical and temperate regions have suggested that AMF abundance may decline as a result of agricultural intensification [25-27]. Whilst reports of AM hyphal lengths in agricultural soils are becoming increasingly common [28], our knowledge of them in natural ecosystems remains scant. Knowledge about mycelial biomass is important in comprehending the potential roles of fungi in decomposition and nutrient cycling, and plant symbionts. For example, a study by Langley and Hungate [29] demonstrates that the presence of mycorrhizal fungi can alter the rates of above- and below- ground litter decomposition due to chemical changes in the roots and interactions with the decomposer fungi. Also, at present, little is known about the control of diversity of AM fungal communities in tropical soils and; given the increasing importance attached to mycorrhizal fungal diversity for maintenance of ecosystem functioning, a better understanding of the causes of AMF diversity and its loss is deemed necessary.

The mycelial network of AM fungi extends into the soil volume and greatly increases the surface area for the uptake of immobile nutrients, particularly $\mathrm{P}, \mathrm{N}$ and $\mathrm{Cu}$ $[5,13]$. Also, AM symbioses improve plants tolerance to drought and enhance plants' tolerance of or resistance to root pathogens $[9,30]$. Furthermore, networks of AM hyphae play an important role in the formation of stable soil aggregates [31], in the building up of a macroporous structure of soil that allows penetration of water and air and thereby prevents erosion [32]. AMF may stabilize soils up to 5 months after their host's death [33]. It is also accepted that AMF receive all their carbohydrate from the host plant $[34,35]$ and that the association of AMF with roots could create a sink demand for carbohydrate, which could result into up to $20 \%$ drain of carbon from the host plant and could indirectly influence carbon storage in the soils [36]. The Carbon obtained by the host plants can be allocated to fungal structures of functional importance to plants, to AMF, or to both members of the symbiosis $[34,37]$. The allocation of fungal arbuscules and extraradical hyphae can increase plant acquisition of soil resources [38]. Fungal allocation to spores and vesicles (C storage structures) is associated with $\mathrm{C}$ accumulation by AMF [39]. Thus, it can be seen that AMF play an important role in many ecosystems. However, AM fungal diversity and activity in the tropical soils 
have not been adequately studied and understood [40]; and relatively little is known about the effects of land use changes on AMF abundance and activity in the tropical soils. A better understanding of the influence of land use changes on AMF abundance will help in improving their management, thus leading to improved plant productivity in the poor soils. Determining the effects of land use changes on the abundance, and activity of beneficial AMF in the tropical soils will also be useful in designing more sustainable management practices.

As Marshner and Dell [12] report, the external hyphae of AMF can deliver up to $80 \%$ of a plant's $\mathrm{P}$ requirements. Thus, the understanding of the factors that enhance nutrient uptake by AMF is especially important for poor countries where the use of mineral fertilizers is not economically feasible [13]. Mycorrhizal fungi are of high value for ecosystem functioning and sustainability [41]. However, land degradation and soil fertility depletion are considered to be the major threats of this ecosystem functioning and sustainability and thereby frustrating people's efforts towards food security and natural resource conservation in sub-Saharan Africa [42].

Mycorrhizal associations are complex hierarchical systems [43]. At the core of every association is a fungus and a plant living symbiotically [44]. The functioning of this symbiosis is mediated by direct and indirect effects of biotic and abiotic factors of the surrounding rhizosphere, community, and ecosystem [45]. Also, AMF abundance may be directly or indirectly influenced by biotic interactions [46]. Subsequently, soil-borne microorganisms (i.e. fungal symbionts) may either directly compete for host $\mathrm{C}$; or develop a beneficial partnership in which the plant supplies $C$ and the fungus supplies the catalytic elements [47]. The benefit of mycorrhiza formation is believed to depend on the balance between the fungal demand for energy and the plant's needs for nutrients [48]. Negative effects of mycorrhizal colonization on the host plant are expected when the net $C$ costs for fungal maintenance and growth exceed the net benefits obtained from improved nutrient supply [49]. Several studies have indicated that the effect of mycorrhiza on the host plant productivity depends on the amount of nutrients available, and on the host plant nutrient status [31,50].

\section{IMPORTANCE OF MYCORRHIZAL MYCELIAL NETWORKS}

AM hyphal networks have an impact on the soil structure and plant community composition and are therefore important belowground carbon sinks $[18,34]$. AMF hyphae form an extensive network in the soil and; length is a common parameter used in quantifying fungal hyphae [51]. Giasson et al. [52] found out that hyphae of AMF may extend up to $8 \mathrm{~cm}$ from the root surface. For example, in rhizosphere of Ryegrass roots, Tisdall and Oades [53] measured about $55 \mathrm{~m}$ of hypahe per cubic centimetre of the soil. As Olsson et al. [54] suggest the mycelial network of AMF accounts for approximately half of the microbial biomass in grassland soils. For instance, it has been estimated that one gram of soil contains up to $200 \mathrm{~m}$ fungal hyphae [28]. And as Read et al. [55] found out, it is the root-based hyphal network in the soil rather than resting spores that is responsible for infecting seedlings that become established in a natural grassland sward. Soil densities of AMF hyphae in temperate grasslands have been shown to vary with precipitation, soil fertility [38,56], and plant productivity [18]. According to Hunt and Fogel [57], the length of hyphae decreases with an increase of the soil depths. Also, there is an exponential decline in both infection and spore numbers with depth [56].

Extraradical hyphal densities are important with respect to potential ecological selection for different lifehistory strategies under contrasting environmental conditions [58]. This is because the extent of the extraradical mycelium is an important trait of AMF, affecting nutrient supply to host plants and thus probably their fitness and survival [59]. External AM hyphae also produce recalcitrant forms of C, such as chitin and glomalin [34,35], and therefore they might be important contributors to the structural stability of the soil and C sequestration [34,35]. Hyphal length is an important consideration that needs to be integrated into any planning for plant conservation because of the potential contribution [60]. Despite their ubiquity and potential importance for ecosystem structure and functions, surprisingly little is known about the abundance of AM networks in tropical soils. AMF have great potential in the restoration of disturbed land and low fertility soil [61]. A more appropriate management of mycorrhizae in poor agricultural soils is expected to allow substantial reduction in the amount of mineral used without losses in productivity, whereas permitting a more sustainable production management.

\section{AM FUNGAL SPECIES COMPOSITION, HOST RANGE AND INFECTIVITY}

AM fungi vary considerably in their life histories and their effects on soil structure and plant health [62,63]. AMF are also known to vary in their response to the mineral environment of the soil [39]. For instance, it has been shown that differences in AMF species distributions are caused by habitat preferences of taxa, such as differences in the tolerance to high nutrient availability $[64,65]$, $\mathrm{pH}$ and soil type [66,67] and mechanical disturbance [68]. Some species of mycorrhizal fungi decline with nitrogen enrichment while others proliferate [i.e. 69]. As predicted by Wallenda and Kottke [70], AM fungal species with a narrow host range (e.g. conifer specialists) are more ad- 
versely affected than species with a broad range of host plants. When soil phosphorus is not limiting, members of the AM fungal family Gigasporaceae are often dramatically reduced by nitrogen enrichment [71]. On the other hand, when soil phosphorus is in limited supply, nitrogen enrichment increases the populations of Gigasporaceae [72]. This suggests that nitrogen enrichment of phosphorus deficient soils exacerbates phosphorus limitation and increases the net benefits of mycorrhizas.

Taxa of AM fungi vary in growth rate, biomass allocation, and symbiotic effects [62]. For example, Glomaceae and Acaulosporaceae allocate more biomass inside roots, and benefit their host plants through increasing pathogen resistance while Gigasporaceae allocate more biomass outside the roots and are more beneficial for plant phosphorus acquisition [73]. As Brundrett et al. [74] report, members of the Gigasporaceae never form vesicles in plant roots; instead they form clusters of auxiliary cells in the surrounding soil (extraradical). Furthermore, the genus Gigaspora produces intra- and extraradical hyphae that are much thicker than other genera [63]. Mycorrhizal roots on intact plants or germinated spores are best understood as sources of infective hyphae for initiating new sites of colonization of roots [56]. Vesicles formed within roots have been shown to act as propagules for some AM fungi [75]. Extra-matrical vesicles of Gigaspora spp. represent potential propagules [76]. For each species of fungus, the types of propagules may differ widely in their tolerance of some conditions [56]. For example, Jasper et al. [77] showed that hyphae of Acaulospora laevis in the soil completely lose their infectivity with disturbance. Therefore, teasing apart the relationships between the environment and community composition is essential for our understanding of AMF diversity in tropical ecosystems.

\section{INFLUENCE OF GRAZING ON AMF ABUNDANCE}

The abiotic environment, particularly soil fertility, water and sunlight may structure the balance of trade among symbionts [78]. The influence of grazing on soil nutrient availability and host plant productivity [79] may cause variable effects on AMF community composition and structure $[80,81]$. Grazing of pasture grasses in the field has been found to affect the proportion of root length infected by decreasing root length per unit volume of soil [23,82]. Grazing intensity might change the level of mycorrhizal infection in a community by altering the plant composition [56]. Therefore, it is likely that the activity of AMF is an important factor in regulating the cycling of nutrients in undisturbed ecosystems [56]. Because symbiotic AMF depend so heavily upon living plants for C, they will be impacted by any process which alters the belowground C allocation [83]. Grazing can influence the dynamics of nutrient exchange between host plants and AMF [84]. Herbivore grazing can alter leaf photosynthetic rates [85], the aboveground production [79], and the C allocation belowground [83]. The allocation of AMF morphological structures can either increase or decrease depending on the timing and severity of herbivory [86]. Grazers also influence allocation of AMF morphological structures by altering soil nutrient status through direct inputs of $\mathrm{N}$ and $\mathrm{P}$ in dung and urine deposition $[87,88]$.

\section{EFFECT OF SOIL DISTURBANCE ON AMF ABUNDANCE}

Disturbance can affect the occurrence of AM fungi in both agricultural and natural ecosystems. It may change the abundance and distribution of mycorrhizal fungi in several ways [56]. First, it may change the physical, chemical or biological environment of soil leading to either direct effects on AM fungi or indirect effects operating via effects of disturbance on plant growth. Second, a disturbance may change the plant composition of the stand or eliminate host plants leading to changes in the distribution and abundance of AM fungi [56]. The removal of surface soil layers mainly by water erosion decreased markedly both the number of propagules of AM fungi and the extent of mycorrhiza formation [89,90]. The disturbance of soil can decrease mycorrhizal infection. There are several factors that may be responsible for this [77]: there may be effects of tillage on the root growth affecting the extent of root colonization by mycorrhizal fungi [27]. Furthermore, an increase in the intensity of cultivation may also lead to a decrease in mycorrhiza formation in dry beans (Phaseolus vulgaris L.) and this is apparently associated with an increase in soil compaction and a decrease in root growth [91]. The effects of soil disturbance on the formation of mycorrhizas may be associated with a decrease in phosphate uptake after ploughing as opposed to the uptake of plants grown without tillage [25].

\section{RESPONSES OF AMF ABUNDANCE TO ENVIRONMENTAL CHANGES}

In the mid-1970s, it was recognized that land cover change modifies surface albedo and thus surface atmosphere energy exchanges, which have an impact on regional climate [92]. A much broader range of impacts of land use and cover change on ecosystem goods and services include impacts on biotic diversity worldwide [93], soil degradation, and the ability of biological systems to support human needs [94]. Land use and cover changes also determine the vulnerability of places and people to climate change $[95,96]$. When aggregated globally, land use and cover changes significantly affect central aspects 
of the functioning of earth systems [97]. In predicting how land use changes affect land degradation, feedback on livelihood strategies from land degradation, and vulnerability of places and people in the face of land use and cover changes require thorough understanding of the dynamics of human-environment interactions associated with land use change [98].

During the last century, land use and cover have changed drastically in the tropics due to changing economy and growing population [99]. Natural vegetation covers have given way not only to cropland but also to pasture. Globally, concerns about the changes in land use and cover emerged due to the realization that land surface processes influence climate and that change in these processes have an impact on the ecosystem goods and services [97]. The impacts of primary concern are the negative effects of land use change on biological diversity, soil degradation and the ability of biological systems to support human needs. One way by which plants can potentially increase ecosystem productivity and stability is by forming mycorrhizal associations [11,100,101]. Plants are most likely to form associations with and benefit from mycorrhizal fungi under conditions in which availability of one or more soil nutrients, including water, is low $[30,102,103]$. Tropical savannah soils have been eroded and deprived of their nutrients leading to reduced plant productivity [104]. AMF are of particular importance to the plants in the soils that are nutrient-poor $[13,24]$. Moreover, AMF may be used as sensitive indicators of ecological soil quality if they respond to environmental variation in a predictable way [105].

Land use practices have placed new pressures on plant-mycorrhizal symbiosis and are evidently a threat to AMF [106]. Therefore, agricultural management practices might affect AMF communities both qualitatively and quantitatively $[31,62,107]$. Studies have shown that crop rotation, fertilization, and tillage affect the composition and diversity of AMF communities as well as spore and mycelium densities in temperate and tropical agroecosystems $[26,108]$. Tillage physically disrupt soil aggregates and AM hyphal networks which deteriorates soil structure, lessens fertility and nutrient cycling, and results into more $\mathrm{C}$ allocation within fungal hyphae to re-establishing these networks and less $\mathrm{C}$ to glomalin formations [109]. The disturbance resulting from agricultural activities has been shown to decrease AMF species richness and infectivity [110]. In some environments, cultivation through tillage and fertilizer application has led to fewer species of AM fungi [111]. Continuous cropping with inadequate external inputs has caused depletion of nutrients such as phosphorus (P) and nitrogen $(\mathrm{N})$ in the tropical soils [112]. In no-till and reduced-tillage systems, maintenance of the integrity of the hyphal network contributes to a rapid AMF infectivity and efficient nutrient uptake [13,113]. Non-tillage practices along with continuous cropping system using mycorrhizal host crops, and reducing mineral fertilizers, enhance the plant-mycorrhizal symbiotic relationship [18]. The AMF diversity occurring over a broad range of the tropical natural systems has not yet been investigated. Studies have been done in temperate and agricultural settings [114] but little is known about the effects of land use and cover changes in natural systems in the tropics. Information about species composition of AMF community appears important in understanding mycorrhizal function in the ecosystems [115]. It is evident that AMF are crucial for the functioning of terrestrial ecosystems. Therefore, understanding the impact of land use and cover changes on AMF abundance in the tropical soils is crucial.

\section{EFFECT OF SOIL NUTRIENTS ON MYCORRHIZAL INFECTION}

The relationships between the level of mycorrhizal colonization and soil chemical and physical properties are variable [116]. High levels of infection have been observed over a wide range of soil $\mathrm{pH}$ and soil phosphate levels and [55,117]. It seems that changes in soil $\mathrm{pH}$ in the field will affect the proportion of colonization associated with particular fungal species but are unlikely to change the total extent of colonization [56]. There are, however, marked differences among species of AM fungi in the effects of soil properties on their distribution and abundance [56]. For example, some species of AM fungi are restricted to either acid or alkaline soils; whereas others occur in both acid and alkaline soils [118]). Negative association has been found between the amounts of extractable phosphate in the soils and the abundance of AM fungi as assessed by infection [119,120]. It has been shown that some species of AM fungi differed in the extent to which phosphate decreased mycorrhiza formation [121]. AMF are also known to vary in their response to the mineral environment of the soil [39]. There are critical ranges of soil-solution $\mathrm{P}$ concentration at which the host-fungus association is truly mutualistic, that is, whereby the benefit each partner derives from the association outweighs the costs [5,113]. As Habte and Osorio [113] suggest, if $\mathrm{P}$ concentration in the soil is suboptimal for mycorrhizal function, AMF symbiotic effectiveness is reduced, and the fungus and the host may compete for scarce P. When solution P concentration is much above the optimum for a given host-fungus combination, mycorrhizal colonization will be suppressed [113]. There is also considerable information on the negative effects of nitrogen fertilizer on mycorrhizal formation [122]. Hyphal growth tends to decrease under fertilization [123].

Studies of agricultural systems have shown that high levels of fertilization can select AMF that are less bene- 
ficial or even parasitic on their host plants [44,124]. Additionally, high levels of nitrogen fertilization can decrease colonization by mycorrhizal fungi [9] and lead to a significant change in mycorrhizal community structure [125]. The adverse effect of high soil P levels on AM formation is well documented and is mainly caused by higher $\mathrm{P}$ concentrations in the roots $[56,77,126]$. It has also been shown that high $\mathrm{P}$ levels in the soil can reduce not only spore germination and hyphal growth from the germinated spores [127] but also early colonization of the roots and growth of the extraradical mycelium [128]. A comparative study across North American grasslands showed that nitrogen fertilization reduces AM hyphal densities in phosphorus rich soil, but increases AM hyphal densities when phosphorus is in limited supply [38]. Adding phosphate fertilizers has been shown to decrease the level of mycorrhizal infection in a range of agricultural crops [129]. For example, Nitrogen applications to wheat decreased spore numbers and mycorrhizal infection [56]. However, few studies have been done on the effects of nutrients, other than phosphorus, on the abundance and distribution of AMF in the field [56].

Investigating how AMF abundance vary with changing levels of soil $\mathrm{N}$ and $\mathrm{P}$ in tropical grasslands will further advance our understanding of the factors controlling mycorrhizas. This is because unlike temperate grasslands, there is virtually no seasonal temperature fluctuation in tropical grasslands. Decomposition and mineralization processes are more likely to be controlled by land use, grazing pressures and seasonal moisture deficit in tropical grasslands as opposed to temperate grasslands. There are however only a few studies that dealt with the effects of $\mathrm{P}$ on the extraradical mycelium of AM fungi; and no attempts have been made to investigate its effects on the root-soil partitioning in these fungi. As Howeler et al. [130] suggest AM hyphae have a lower threshold for uptake of phosphorus than that of non-colonized plant roots. In the soil with a high capacity to immobilize phosphorus and low availability of phosphate, as is the case in many tropical soils, AM can be of great benefit to plants [13,129]. High phosphorus can inhibit AM colonization of plant roots, reduce formation of entry points and vesicles [131], and decrease the length of external hyphae associated with AM [126], consequently diminishing nutrient uptake and host benefit from AM [132].

\section{CONSERVATION IMPLICATIONS}

It should be apparent from the preceding discussion that Arbuscular mycorrhizal symbioses play fundamental roles in shaping plant communities and terrestrial ecosystems. The significance of mycorrhizal fungi lies on the fact that they connect the primary producers of ecosystems, plants, to the heterogeneously distributed ( $\mathrm{N}$ and $\mathrm{P}$ ) nutrients which are required for their growth.
Mycorrhizal fungi are of high value for the ecosystem functioning and sustainability. A more appropriate management of mycorrhizae in poor soils would allow substantial reduction in the amount of minerals used without losses in productivity, while at the same time permitting a more sustainable production management. Studies on AMF species diversity and their functions across land use types are crucial in understanding the impact of land use changes on ecosystem services. For example, ecologists who conduct field studies of the impacts of land use changes on mycorrhizal colonization and community composition could benefit from collaboration with plant physiologists to provide mechanistic insights. Currently, most studies of mycorrhizal mediation of below ground processes have examined individual plant-fungus pairs or interactions among individual mycorrhizas and biota or abiotic conditions. Although this scale of inquiry provides precise understanding of specific plant-fungal systems, it cannot provide meaningful information about mycorrhizal function within communities and ecosystems [133]. Also, we still have much to learn regarding the extent of mycorrhizal fungal diversity. Among species of mycorrhizal fungi, there is very little knowledge of functional attributes such as stress tolerance and nutrient uptake efficiency. Comparative studies of natural systems will improve our understanding of responses to environmental and climatic perturbations. This new knowledge is an important prerequisite for future and sustainable management of terrestrial ecosystems. It is critical to gain a clearer understanding of functional variation among AM fungal species to guide conservation and restoration efforts.

\section{ACKNOWLEDGEMENTS}

Funding from the National Science Foundation (NSF) award No. 0842230 to Prof. Mark Richie for the work reviewed here is gratefully acknowledged. We thank Prof. Thomas R. Horton of the State University of New York College of Environmental Science and Forestry (SUNY-ESF) for many helpful discussions. The Department of Biology at Syracuse University is also acknowledged for providing Geofrey Soka with the financial assistance through Teaching Assistantship and Tuition Scholarship which supported his studies in the USA.

\section{REFERENCES}

[1] Smith, S.E. and Read, D.J. (2008) Mycorrhizal symbiosis. 3rd Edition, Academic Press, New York.

[2] Redecker, D., Kodner, R. and Graham, L.E. (2000) Glomalean fungi from the Ordovician. Science, 289, 19201921. http://dx.doi.org/10.1126/science.289.5486.1920

[3] Fitter, A.H. (2005) Darkness visible, reflections on underground ecology. Journal of Ecology, 93, 231-243. http://dx.doi.org/10.1111/j.0022-0477.2005.00990.x

[4] Santos-González, J.C., Finlay, R.D. and Tehler, A. (2007) 
Seasonal dynamics of arbuscular mycorrhizal root colonization in a semi-natural grassland. Applied and Environmental Microbiology, 73, 5613-5623. http://dx.doi.org/10.1128/AEM.00262-07

[5] Brundrett, M. (2004) Diversity and classification of mycorrhizal associations. Biol. Rev., 79, 473-495. http://dx.doi.org/10.1017/S1464793103006316

[6] Power, M.E. and Mills, L.S. (1995) The keystone cops meet in Hilo. Tree, 10, 182-184. http://dx.doi.org/10.1016/S0169-5347(00)89047-3

[7] Atayese, M.O., Awotoye, O.O., Osonubi, O. and Mulongo, K. (1993) Comparison of the influence of hedgerow woody legumes and cassava at the top and base of a hill slope in alley cropping system. Biology and Fertility of Soils, 16, 198-204.

http://dx.doi.org/10.1007/BF00361408

[8] Sieverding, E. (1991) Vesicular-arbuscular mycorrhiza man-agement in tropical agro-systems. German Technical Cooperation (GTZ), Eschborn.

[9] Smith, S.E. and Read, D.J. (1997) Mycorrhizal symbiosis. 2nd Edition, Academic Press, New York.

[10] Borowicz, V. (2001) Do arbuscular mycorrhizal fungi alter plant-pathogen relations? Ecology, 82, 3057-3068. http://dx.doi.org/10.2307/2679834

[11] Van der Heijden, M.G.A., Klironomos, J.N., Ursic, M., Mou-Toglis, P., Streitwolf-Engel, R., Boller, T., Wiemken, A. and Sanders, I.R. (1998) Mycorrhizal fungal diversity determines plant biodiversity, ecosystem variability and productivity. Nature, 396, 69-72. http://dx.doi.org/10.1038/23932

[12] Marschner, H. and Dell, B. (1994) Nutrient uptake in mycorrhizal symbiosis. Plant Soil, 159, 89-102.

[13] Johnson, N.C., Wilson, G.W.T., Bowker, M.A., Wilson, J.A. and Miller, R.A. (2010) Resource limitation is a driver of local adaptation in mycorrhizal symbioses. PNAS, 107, 2093-2098. http://dx.doi.org/10.1073/pnas.0906710107

[14] Smith, F.A., Grace, E.J. and Smith, S.E. (2009) More than a carbon economy: Nutrient trade and ecological sustainability in facultative arbuscular mycorrhizal symbioses. New Phytologist, 182, 347-358. http://dx.doi.org/10.1111/j.1469-8137.2008.02753.x

[15] Reinhardt, D. (2007) Programming good relations-Development of the arbuscular mycorrhizal symbiosis. Current Opinion in Plant Biology, 10, 98-105. http://dx.doi.org/10.1016/j.pbi.2006.11.001

[16] Bonfante, P. and Genre, A. (2008) Plants and arbuscular mycorrhizal fungi: An evolutionary developmental perspective. Trends in Plant Science, 13, 492-498. http://dx.doi.org/10.1016/j.tplants.2008.07.001

[17] Jefwa, J.M., Mwangi, L.M., Odee, D. and Mugambi, G. (2004) Prelimi-nary studies on mycorrhizal symbiosis in plant conser-vation forestry and farming systems in Kenya. Journal of Tropical Microbiology, 3, 48-62.

[18] Rilling, C.M. (2004) Arbuscular Mycorrhizae and terrestrial ecosystem process. Ecology Letters, 7, 740-754. http://dx.doi.org/10.1111/j.1461-0248.2004.00620.x
[19] Hu, Y., Rillig, M.C., Xiang, D., Hao, Z. and Chen, B. (2013) Changes of AM fungal abundance along environmental gradients in the arid and semi-arid grasslands of northern China. PLOS ONE, 8, 1-10.

[20] Klironomos, J.N. (2002) Feedback with soil biota contributes to plant rarity and invasiveness in communities. Nature, 417, 67-70. http://dx.doi.org/10.1038/417067a

[21] McGuire, K.L., Henkel, T.W., Granzowdela, C.I., Villa, G., Edmund, F. and Andrew, C. (2008) Dual mycorrhizal colonization of forest-dominating tropical trees and the mycorrhizal status of non-dominant tree and liana species. Mycorrhiza, 18, 217-222. http://dx.doi.org/10.1007/s00572-008-0170-9

[22] IPCC, Houghton, J.T., Ding, Y., Griggs, D.J., Noguer, M., van der Linden, J.P. and Xiaosu, D. (2001) The scientific basis. Cambridge University Press, Cambridge.

[23] Yang, W., Zheng, Y., Gao, C., He, X., Ding, Q., Kim, Y., Rui, Y., Wang, S. and Guo, L. (2013) The arbuscular mycorrhizal fungal community response to warming and grazing differs between soil and roots on the QinghaiTibetan Plateau. PLOS ONE, 8, 1-11. http://dx.doi.org/10.1371/journal.pone.0076447

[24] Jeffries, P., Gianinazzi, S., Perotto, S., Turnau, K. and Barea, J.M. (2003) The contribution of arbuscular mycorrhizal fungi in sustainable maintenance of plant health and soil fertility. Biology and Fertility of Soils, 37, 1-16.

[25] O’Halloran, I.P., Miller, M.H. and Arnold, G. (1986) Absorption of P by corn (Zea mays L.) as influenced by soil disturbance. Canadian Journal of Plant Science, 66, $287-$ 302.

[26] Oehl, F., Sieverding, E., Ineichen, K., Mäder, P., Boller, T. and Wiemken, A. (2003) Impact of land use intensity on the species diversity of arbuscular mycorrhizal fungi in agro-ecosystems of Central Europe. Applied and Environmental Microbiology, 69, 2816-2824. http://dx.doi.org/10.1128/AEM.69.5.2816-2824.2003

[27] Borie, F., Rubio, R., Rouanet, J.L., Morales, A., Borie, G. and Rojas, C. (2006) Effects of tillage systems on soil characteristics, glomalin and mycorrhizal propagules in a Chilean Ultisol. Soil \& Tillage Research, 88, 253-261. http://dx.doi.org/10.1016/j.still.2005.06.004

[28] Leake, J., Johnson, D., Donnelly, D., Muckle, G., Boddy, L. and Read, D. (2004) Networks of power and influence: The role of mycorrhizal mycelium in controlling plant communities and agroecosystem functioning. Canadian Journal of Botany, 82, 1016-1045. http://dx.doi.org/10.1139/b04-060

[29] Langley, J.A. and Hungate, B.A. (2003) Mycorrhizal controls on belowground litter quality. Ecology, 84, 2302 2312. http://dx.doi.org/10.1890/02-0282

[30] Auge, R.M. (2001) Water relations, drought and vesicular-arbuscular mycorrhizal symbiosis. Mycorrhiza, 11, 342. http://dx.doi.org/10.1007/s005720100097

[31] Cavagnaro, T.R., Jackson, L.E., Six, J., Ferris, H., Goyal, S., Asami, D. and Scow, K.M. (2006) Arbuscular mycorrhizas, microbial communities, nutrient availability, and soil aggregates in organic tomato production. Plant and Soil, 282, 209-225. 
http://dx.doi.org/10.1007/s11104-005-5847-7

[32] Rillig, M.C., Wright, S.F. and Eviner, V.T. (2002) The role of arbuscular mycorrhizal fungi and glomalin in soil aggregation: Comparing effects of five plant species. Plant and Soil, 238, 325-333. http://dx.doi.org/10.1023/A:1014483303813

[33] Tisdall, J.M. and Oades, J.M. (1980) The effect of crop rotation on aggregation in a red-brown earth. Australian Journal of Soil Research, 18, 423-433. http://dx.doi.org/10.1071/SR9800423

[34] Le Tacon, F., Zeller, B., Plain, C., Hossann, C., Bréchet, C. and Robin, C. (2013) Carbon transfer from the host to tuber melanosporum mycorrhizas and ascocarps followed using a 13C pulse-labeling technique. PLoS ONE, 8, Article ID: e64626.

http://dx.doi.org/10.1371/journal.pone.0064626

[35] Zhu, Y.G. and Miller, R.M. (2003) Carbon cycling by arbuscular my-corrhizal fungi in soil-plant systems. Trends in Plant Science, 8, 407-409.

http://dx.doi.org/10.1016/S1360-1385(03)00184-5

[36] Graham, J.H. (2000) Assessing costs of arbuscular mycorrhizal symbiosis in agroecosystems. In: Podila, G.K. and Douds Jr., D.D., Eds., Current Advances in Mycorrhizae Research, The American Phytopahthological Society Press, St. Paul, 127-140.

[37] Olsson, P.A., Jakobsen, I. and Wallander, H. (2002) Foraging and resource allocation strategies of mycorrhizal fungi in a patchy environment. Ecological Studies, 157, 93-115. http://dx.doi.org/10.1007/978-3-540-38364-2 4

[38] Johnson, N.C., Rowland, D.L., Corkidi, L., Egerton-Warburton, L. and Allen, E.B. (2003) Nitrogen enrichment alters mycorrhizal allocation at five mesic to semiarid grass-lands. Ecology, 84, 1895-1908. http://dx.doi.org/10.1890/0012-9658(2003)084[1895:NE AMAA]2.0.CO;2

[39] Bever, J.D., Schultz, P.A., Pringle, A. and Morton, J.B. (2001) Arbuscular mycorrhizal fungi: More diverse than meets the eye, and the ecological tale of why. BioScience, 51, 923-932.

http://dx.doi.org/10.1641/0006-3568(2001)051[0923:AM FMDT]2.0.CO;2

[40] Hawksworth, D.L. (2001) The magnitude of fungal diversity: The 1.5 million species estimate revisited. Mycological Research, 105, 1422-1432. http://dx.doi.org/10.1017/S0953756201004725

[41] Sanders, I.R. (2010) 'Designer' mycorrhizas? Using natural genetic variation in AM fungi to increase plant growth. ISME Journal, 4, 1081-1083.

http://dx.doi.org/10.1038/ismej.2010.109

[42] Cardoso, I.M. and Kuyper, T.W. (2006) Mycorrhizas and tropical soil fertility. Agriculture, Ecosystems \& Environment, 116, 72-84.

http://dx.doi.org/10.1016/j.agee.2006.03.011

[43] O'Neill, E.G., O’Neill, R.V. and Norby, R.J. (1991) Hierarchy theory as a guide to mycorrhizal research on largescale problems. Environmental Pollution, 73, 271-284. http://dx.doi.org/10.1016/0269-7491(91)90054-Z

[44] Johnson, N.C., Graham, J.H. and Smith, F.A. (1997) My- corrhizal associations along the mutualism-parasitism continuum. New Phytologist, 135, 575-586. http://dx.doi.org/10.1046/j.1469-8137.1997.00729.x

[45] Linderman, R.G. (1988) Mycorrhizal interactions with the rhizosphere microflora: The mycorrhizosphere effect. Phytopathology, 78, 366-371.

[46] Reinhard, S., Weber, E., Martin, P. and Marschner, H. (1994) Influence of phosphorus supply and light intensity on mycorrhizal response in Pisum-Rhizobium-Glomus symbiosis. Experientia, 50, 890-896.

http://dx.doi.org/10.1007/BF01923475

[47] Wellings, N.P., Wearing, A.H. and Thompson, J.P. (1991) Vesicular-arbuscular mycorrhizae (VAM) improve phosphorus and zinc nutrition and growth of pigeon pea in a Vertisol. Australian Journal of Agricultural Research, 42, 835-845. http://dx.doi.org/10.1071/AR9910835

[48] Corrêa, A., Hampp, R., Magel, E. and Martins-Loução, M. (2011) Carbon allocation in ectomycorrhizal plants at limited and optimal $\mathrm{N}$ supply: An attempt at unraveling conflicting theories. Mycorrhiza, 21, 35-51. http://dx.doi.org/10.1007/s00572-010-0309-3

[49] Tuomi, J., Kytöviita, M. and Härdling, R. (2001) Cost efficiency of nutrient acquisition and the advantage of mycorrhizal symbiosis for the host plant. Oikos, 92, 62-70. http://dx.doi.org/10.1034/j.1600-0706.2001.920108.x

[50] Janos, D.P. (2007) Plant responsiveness to mycorrhizas differs from dependence upon mycorrhizas. Mycorrhiza, 17, 75-91.

[51] Hynes, M.M., Zasoski, R.J. and Bledsoe, C.S. (2008) Evaluation of two techniques for quantification of hyphal biomass. In: Merenlender, A., McCreary, D. and Purcell, K.L., Eds., 2008. Proceedings of the 6th California oak Symposium: Today's Challenges, Tomorrow's Opportunities. General Technical ReportsPSW-GTR-217. Department of Agriculture, Forest Service, Pacific Southwest Research Station, Albany, 139-148.

[52] Giasson, P., Karam, A. and Jaouich, A. (2008) Arbuscular mycorrhizae and alleviation of soil stresses on plant growth. In: Siddiqui, Z.A., Akhtar, M.S. and Futai, K., Eds., Mycorrhizae: Sustainable Agriculture and Forestry, Springer and Business Media B.V., 99-134. http://dx.doi.org/10.1007/978-1-4020-8770-7 4

[53] Tisdall, J.M. and Oades, J.M. (1979) Stabilization of soil aggregates by the root systems of ryegrass. Australian Journal of Soil Research, 17, 429-441. http://dx.doi.org/10.1071/SR9790429

[54] Olsson, P.A., Thingstrup, I., Jakobsen, I. and Baath, E. (1999) Estimation of the biomass of arbuscular mycorrhizal fungi in a linseed field. Soil Biology and Biochemistry, 31, 1879-1887. http://dx.doi.org/10.1016/S0038-0717(99)00119-4

[55] Read, D.J., Koucheki, H.K. and Hodgson, J. (1976) Vesicular-arbuscular mycorrhiza in natural vegetation systems. New Phytologist, 77, 641-653. http://dx.doi.org/10.1111/j.1469-8137.1976.tb04657.x

[56] Abbott, L.K. and Robson, A.D. (1991) Factors influencing the occurrence of vesicular-arbuscular mycorrhizas. Agriculture, Ecosystems \& Environment, 35, 121-150. 
[57] Hunt, G.A. and Fogel, R. (1983) Fungal hyphal dynamics in a western Oregon Douglas-fir stand. Soil Biology and Biochemistry, 15, 641-649. http://dx.doi.org/10.1016/0038-0717(83)90027-5

[58] Brito, I., De Carvalho, M. and Goss, M.J. (2011) Summer survival of arbuscular mycorrhiza extraradical mycelium and the potential for its management through tillage options in Mediterranean cropping systems. Soil Use and Management, 27, 350-356.

[59] Dodd, J.C. (2000) The role of arbuscular Mycorrhizal Fungi in agro- and natural ecosystems. Outlook on Agriculture, 29, 55-62. http://dx.doi.org/10.5367/000000000101293059

[60] Utobo, E.B., Ogbodo, E.N. and Nwogbaga, A.C. (2011) Techniques for extraction and quantification of arbuscular mycorrhizal fungi. Libyan Agriculture Research Center Journal International, 2, 68-78.

[61] Quilambo, O.Q. (2003) The vesicular-arbuscular mycorrhizal symbiosis. African Journal of Biotechnology, 2, 539546.

[62] Miller, R.M., Reinhardt, D.R. and Jastrow, J.D. (1995) External hyphal production of vesicular-arbuscular mycorrhizal fungi in pasture and tall grass prairie communities. Oecologia, 103, 17-23.

http://dx.doi.org/10.1007/BF00328420

[63] Klironomos, J.N., McCune, J., Hart, M. and Neville, J. (2000) The influence of arbuscular mycorrhizae on the relationship between plant diversity and productivity. Ecology Letters, 3, 137-141. http://dx.doi.org/10.1046/j.1461-0248.2000.00131.x

[64] Egerton-Warburton, L.M., Johnson, N.C. and Allen, E.B. (2007) Mycorrhizal community dynamics following nitrogen fertilization: A cross-site test in five grasslands. Ecological Monographs, 77, 527-544. http://dx.doi.org/10.1890/06-1772.1

[65] Porras-Alfaro, A., Herrera, J., Natvig, D.O. and Sinsabaugh, R.L. (2007) Effect of long-term nitrogen fertilization on mycorrhizal fungi associated with a dominant grass in a semiarid grassland. Plant and Soil, 296, 65-75. http://dx.doi.org/10.1007/s11104-007-9290-9

[66] Lekberg, Y., Koide, R.T., Rohr, J.R., Aldrich-Wolfe, L. and Morton, J.B. (2007) Role of niche restrictions and dispersal in the composition of arbuscular mycorrhizal fungal communities. Journal of Ecology, 95, 95-105. http://dx.doi.org/10.1111/j.1365-2745.2006.01193.x

[67] Oehl, F., Laczko, E., Bogenrieder, A., Stahr, K., Bösch, R., van der Heijden, M. and Sieverding, E. (2010) Soil type and land use intensity determine the composition of arbuscular Mycorrhizal Fungal communities. Soil Biology and Biochemistry, 42, 724-738. http://dx.doi.org/10.1016/j.soilbio.2010.01.006

[68] Schnoor, T.K., Lekberg, Y., Rosendahl, S. and Olsson, P.A. (2011) Mechanical soil disturbance as a determinant of arbuscular mycorrhizal fungal communities in semi-natural grassland. Mycorrhiza, 21, 211-220. http://dx.doi.org/10.1007/s00572-010-0325-3

[69] Lilleskov, E.A., Fahey, T.J. and Lovett, G.M. (2001) Ectomycorrhizal fungal aboveground community change over an atmospheric nitrogen deposition gradient. Ecological Applications, 11, 397-410. http://dx.doi.org/10.1890/1051-0761(2001)011[0397:EFA CCO]2.0.CO;2

[70] Wallenda, T. and Kottke, I. (1998) Nitrogen deposition and ectomycorrhizas. New Phytologist, 139, 169-187. http://dx.doi.org/10.1046/j.1469-8137.1998.00176.x

[71] Egerton-Warburton, L.M. and Allen, E.B. (2000) Shifts in arbuscular mycorrhizal communities along an anthropogenic nitrogen deposition gradient. Ecological Applications, 10, 484-496.

http://dx.doi.org/10.1890/1051-0761(2000)010[0484:SIA MCA]2.0.CO;2

[72] Eom, A.H., Harnett, D.C., Wilson, G.W.T. and Figge, D.A.H. (1999) The effect of fire, mowing and fertilizer amendment on arbuscular mycorrhizas in tallgrass prairie. American Midland Naturalist, 142, 55-70. http://dx.doi.org/10.1674/0003-0031(1999)142[0055:TE OFMA]2.0.CO;2

[73] Klironomos, J.N., McCune, J. and Moutoglis, P. (2004) Species of arbuscular mycorrhizal fungi affect mycorrhizal responses to simulated herbivory. Applied Soil Ecology, 26, 133-141. http://dx.doi.org/10.1016/j.apsoil.2003.11.001

[74] Brundrett, M.C., Piche, Y. and Peterson, R.L. (1984) A new method for observing the morphology of vesiculararbuscular mycorrhizae. Canadian Journal of Botany, 62, 2128-2134.

[75] Biermann, B. and Linderman, R.G. (1983) Use of vesiculararbuscular mycorrhizal roots, intraradical vesicles and extraradical vesicles as inoculum. New Phytologist, 95, 97-105. http://dx.doi.org/10.1111/j.1469-8137.1983.tb03472.x

[76] Jabaji-Hare, S.H., Piche, Y. and Fortin, J.A. (1986) Isolation and structural characterization of soil-borne auxiliary cells of Gigaspora margarita Becker and Hall, a vesicular arbuscular mycorrhizal fungus. New Phytologist, 103, 777784.

http://dx.doi.org/10.1111/j.1469-8137.1986.tb00852.x

[77] Jasper, D.A., Abbot, L.K. and Robson, A.D. (1989) Hyphae of a vesicular-arbuscular mycorrhizal fungus maintain infectivity in dry soil, except when the soil is disturbed. New Phytologist, 112, 101-107. http://dx.doi.org/10.1111/j.1469-8137.1989.tb00314.x

[78] Azcon, R., Rubio, R. and Barea, J.M. (1991) Selective interactions between different species of mycorrhizal fungi and Rhizobium meliloti strains, and their effects on growth, N2-fixation (N15) and nutrition of Medicago sativa L. New Phytologist, 117, 399-404. http://dx.doi.org/10.1111/j.1469-8137.1991.tb00003.x

[79] Frank, D.A. and McNaughton, S.J. (1993) Evidence for the promotion of aboveground grassland production by native large herbivores in Yellowstone National Park. Oecologia, 96, 157-161. http://dx.doi.org/10.1007/BF00317727

[80] Eom, A.H., Wilson, G.W.T. and Hartnett, D.C. (2001) Effects of ungulate grazers on arbuscular mycorrhizal symbiosis and fungal community structure in tallgrass prairie. Mycologia, 92, 233-242. http://dx.doi.org/10.2307/3761643 
[81] Bai, G., Bao, Y.Y., Du, G.X. and Qi, Y.L. (2013) Arbuscular mycorrhizal fungi associated with vegetation and soil parameters under rest grazing management in a desert steppe ecosystem. Mycorrhiza, 23, 289-301. http://dx.doi.org/10.1007/s00572-012-0468-5

[82] Trent, J.D., Wallace, L.L., Svejcar, T.J. and Christiansen, S. (1988) Effect of grazing on growth, carbohydrate pools, and mycorrhizae in winter wheat. Canadian Journal of Plant Science, 68, 115-120. http://dx.doi.org/10.4141/cjps88-012

[83] Frank, D.A., Kuns, M.M. and Guido, D.R. (2002) Consumer control of grassland plant production. Ecology, 83, 602-606.

http://dx.doi.org/10.1890/0012-9658(2002)083[0602:CC OGPP]2.0.CO;2

[84] Gehring, C.A. and Whitham, T.G. (2002) Mycorrhizae herbivore interactions: Population and community consequences. In: van der Heijden, M.G.A. and Sanders, I.R. Eds., Mycorrhizal Ecology, Springer, Berlin, 295-320.

[85] McNaughton, S.J. (1979) Grazing as an optimization process: Grass ungulate relationships in the Serengeti. American Naturalist, 113, 691-703. http://dx.doi.org/10.1086/283426

[86] Gange, A.C. (2007) Insect-mycorrhizal interactions: Patterns, processes, and consequences. In: Ohgushi, T., Craig, T.P. and Price, P.W., Eds., Ecological Communities: Plant Mediation in Indirect Interaction Webs. Cambridge University Press, London, 124-143. http://dx.doi.org/10.1017/CBO9780511542701.007

[87] Schnyder, H., Locher, F. and Auerswald, K. (2010) Nutrient redistribution by grazing cattle drives patterns of topsoil $\mathrm{N}$ and $\mathrm{P}$ stocks in a low-input pasture ecosystem. Nutrient Cycling in Agroecosystems, 88, 183-195. http://dx.doi.org/10.1007/s10705-009-9334-z

[88] van der Waal, C., et al. (2011) Large herbivores may alter vegetation structure of semi-arid savannas through soil nutrient mediation. Oecologia, 165, 1095-1107. http://dx.doi.org/10.1007/s00442-010-1899-3

[89] Powell, C.L. (1981) Inoculation of barley with efficient mycorrhizal fungi stimulates seed yield. Plant and Soil, 59, 487-489. http://dx.doi.org/10.1007/BF02184553

[90] Habte, M. (1989) Impact of simulated erosion on the abundance and activity of indigenous vesicular-arbuscular mycorrhizal endophytes in an oxisol. Biology and Fertility of Soils, 7, 164-167. http://dx.doi.org/10.1007/BF00292576

[91] Mulligan, M.F., Smucker, A.J.M. and Safir, G.F. (1985) Tillage modifications of dry edible bean root colonization by VAM fungi. Agronomy Journal, 77, 140-142. http://dx.doi.org/10.2134/agronj1985.0002196200770001 $\underline{0033 x}$

[92] Sagan, C., Toon, O.B. and Pollack, J.B. (1979) Anthropogenic albedo changes and the earth's climate. Science, 206, 1363-1368.

http://dx.doi.org/10.1126/science.206.4425.1363

[93] Sala, O.E., Chapin, F.S., Armesto, J.J., Berlow, E. Bloomfield, J., et al. (2000) Biodiversity-global biodiversity scenarios for the year 2100. Science, 287, 1770-1774. http://dx.doi.org/10.1126/science.287.5459.1770

[94] Trimble, S.W. and Crosson, P. (2000) Land use US soil erosion rates: Myth and reality. Science, 289, 248-250. http://dx.doi.org/10.1126/science.289.5477.248

[95] Vitousek, P.M., Mooney, H.A., Lubchenco, J. and Melillo, J.M. (1997) Human domination of earth's ecosystems. Science, 277, 494-499. http://dx.doi.org/10.1126/science.277.5325.494

[96] Odada, E.O., Ochola, W.O. and Olago, D.A. (2009) Drivers of ecosystem change and their impacts on human well-being in Lake Victoria basin. African Journal of Ecology, 47, 46-54.

http://dx.doi.org/10.1111/j.1365-2028.2008.01049.x

[97] Lambin, E.F., Geist, H.J. and Lepers, E. (2003) Dynamics of land-use and land-cover change in tropical regions. Annual Review of Environment and Resources, 28, 205241. http://dx.doi.org/10.1146/annurev.energy.28.050302.1054 $\underline{59}$

[98] Ramankutty, N. and Foley, J.A. (1999) Estimating historical changes in global land cover: Croplands from 1700 to 1992. Global Biogeochemical Cycles, 13, 997-1027. http://dx.doi.org/10.1029/1999GB900046

[99] Meyer, W.B. and Turner, B.L. (1992) Human population growth and global land-use/cover change. Annual Review of Ecology and Systematics, 23, 39-61. http://dx.doi.org/10.1146/annurev.es.23.110192.000351

[100] Eriksson, A. (2001) Arbuscular mycorrhiza in relation to management history, soil nutrients and plant species diversity. Plant Ecology, 155, 129-137. http://dx.doi.org/10.1023/A:1013204803560

[101] Hartnett, D.C. and Wilson, G.W.T. (2002) The role of mycorrhizas in plant community structure and dynamics: Lessons from grasslands. Ecology, 80, 1187-1195. http://dx.doi.org/10.1890/0012-9658(1999)080[1187:MIP CSA]2.0.CO;2

[102] Hoeksema, J.D. and Schwartz, M.W. (2003) Expanding comparative advantage biological market models: Contingency of mutualism on partners' resource requirements and acquisition trade-offs. Proceeding of the Royal Society of London B, 270, 913-919. http://dx.doi.org/10.1098/rspb.2002.2312

[103] Jones, M.D. and Smith, S.E. (2004) Exploring functional definitions of mycorrhizas: Are mycorrhizas always mutualisms? Canadian Journal of Botany, 82, 1089-1109. http://dx.doi.org/10.1139/b04-110

[104] Pimentel, D. (2006) Soil erosion: A food and environmental threat. Environment, Development and Sustainability, 8, 119-137. http://dx.doi.org/10.1007/s10668-005-1262-8

[105] Verbruggen, E., Van Der Heijden, M.G., Weedon, J.T., Kowalchuk, G.A. and Röling, W.F. (2012) Community assembly, species richness and nestedness of arbuscular mycorrhizal fungi in agricultural soils. Molecular Ecology, 21, 2341-2353.

[106] Siddiqui, Z.A. and Pichtel, J. (2008) Mycorrhixae: An overview. In: Siddiqui, Z.A., Akhtar, M.S. and Futai, K., Eds., Mycorrhizae: Sustainable Agriculture and Forestry, 
Springer, Berlin, 1-35. http://dx.doi.org/10.1007/978-1-4020-8770-7_1

[107] Barber, N.A., Kiers, E.T., Theis, N., Hazzard, R.V. and Adler, L.S. (2013) Linking agricultural practices, mycorrhizal fungi, and traits mediating plant-insect interactions. Ecological Applications, 23, 1519-1530. http://dx.doi.org/10.1890/13-0156.1

[108] Jansa, J., Mozafar, A., Anken, T., Ruh, R., Sanders, I.R. and Frossard, E. (2002) Diversity and structure of AMF communities as affected by tillage in a temperate soil. Mycorrhiza, 12, 225-234. http://dx.doi.org/10.1007/s00572-002-0163-z

[109] Nichols, K.A. and Wright, S.F. (2004) Contributions of soil fungi to organic matter in agricultural soils. In: Magdoff, F. and Weil, R., Eds., Functions and Management of Soil Organic Matter in Agro-ecosystems. CRC, Washington, DC, 179-198.

[110] Douds, D.D. and Millner, P.D. (1999) Biodiversity of arbuscular mycorrhizal fungi in agroecosystems. Agriculture, Ecosystems \& Environment, 74, 77-93. http://dx.doi.org/10.1016/S0167-8809(99)00031-6

[111] Schenck, N.C. and Kinloch, R.A. (1980) Incidence of mycorrhizal fungi on six field crops in monoculture on a newly cleared woodland site. Mycologia, 72, 445-456. http://dx.doi.org/10.2307/3759518

[112] Smithson, P.C. and Giller, K.E. (2002) Appropriate farm management practices for alleviating $\mathrm{N}$ and $\mathrm{P}$ deficiencies in low-nutrient soils of the tropics. Plant and Soil, 245, 169-180. http://dx.doi.org/10.1023/A:1020685728547

[113] Habte, M. and Osorio, N.W. (2001) Arbuscular mycorrhizas: Producing and applying arbuscular mycorrhizal inoculum. Department of Tropical Plant and Soil Sciences, College of Tropical Agriculture and Human Resources, University of Hawaii, Honolulu, 47.

[114] Daniell, T.J., Husband, R., Fitter, A.H. and Young, J.P.W. (2001) Molecular diversity of arbuscular mycorrhizal fungi colonising arable crops. FEMS Microbiology Ecology, 36, 203-209. http://dx.doi.org/10.1111/j.1574-6941.2001.tb00841.x

[115] Johnson, N.C. and Pfleger, F.L. (1992) Vesicular-arbuscular mycorrhizae and cultural stress. In: Bethlenfalvay, G.J. and Lindennan, R.G., Eds., Mycorrhizae in Sustainable Agriculture, American Society of Agronomy, Special Publication 54, American Society of Agronomy, 71-99.

[116] Newman, E.I., Heap, A.J. and Lawley, R.A. (1981) Abundance of mycorrhizas and root-surface micro-organisms of Plantago lanceolata in relation to soil and vegetation: A multivariate approach. New Phytologist, 89, 95-108. http://dx.doi.org/10.1111/j.1469-8137.1981.tb04752.x

[117] Jeffries, P., Spyropoulos, T. and Vardavarkis, E. (1988) Vesicular-arbuscular mycorrhizal status of various crops in different agricultural soils of northern Greece. Biology and Fertility of Soils, 5, 333-337. http://dx.doi.org/10.1007/BF00262142

[118] Porter, W.M., Robson, A.D. and Abbott, L.K. (1987) Field survey of the distribution of VA mycorrhizal fungi in relation to soil pH. Journal of Applied Ecology, 24, 659662. http://dx.doi.org/10.2307/2403900
[119] Bolgiano, N.C., Safir, G.R. and Warncke, D.D. (1983) Mycorrhizal infection and growth of onion in the field in relation to phosphorus and water availability. Journal of the American Society for Horticultural Science, 108, 819825.

[120] Morita, A. and Konishi, S. (1989) Relationship between vesicular-arbuscular mycorrhizal infection and soil phosphorus concentration in tea fields. Soil Science and Plant Nutrition, 35, 139-143.

http://dx.doi.org/10.1080/00380768.1989.10434745

[121] Thomson, B.D., Robson, A.D. and Abbott, L.K. (1986) Effects of Phosphorus on the formation of mycorrhizas by Gigaspora calospora and Glomus fasciculatum in relation to root carbohydrates. New Phytologist, 103, 751-765. http://dx.doi.org/10.1111/j.1469-8137.1986.tb00850.x

[122] Mosse, B., Powell, C.L. and Hayman, D.S. (1976) Plant growth responses to vesicular-arbuscular mycorrhiza. IX. Interactions between vesicular-arbuscular mycorrhiza, rock phosphate and symbiotic nitrogen fixation. New Phytologist, 76, 331-342. http://dx.doi.org/10.1111/j.1469-8137.1976.tb01468.x

[123] Treseder, K.K. (2004) A meta-analysis of mycorrhizal responses to nitrogen, phosphorus, and atmospheric $\mathrm{CO}_{2}$ in field studies. New Phytologist, 164, 347-355. http://dx.doi.org/10.1111/j.1469-8137.2004.01159.x

[124] Johnson, N.C. (1993) Can fertilization of soil select less mutualistic mycorrhizae? Ecological Applications, 3, 749757. http://dx.doi.org/10.2307/1942106

[125] Parrent, J.L. and Vilgalys, R. (2007) Biomass and compositional responses of ectomycorrhizal fungal hyphae to elevated $\mathrm{CO}_{2}$ and nitrogen fertilization. New Phytologist, 176, 164-174. http://dx.doi.org/10.1111/j.1469-8137.2007.02155.x

[126] Abbott, L.K., Robson, A.D. and De Boer, G. (1984) The effect of phosphorus on the formation of hyphae in soil by the vesicular-arbuscular mycorrhizal fungus, Glomus fasciculatum. New Phytologist, 97, 437-446. http://dx.doi.org/10.1111/j.1469-8137.1984.tb03609.x

[127] Miranda, J.C.C. and Harris, P.J. (1994) Effects of soil phosphorus on spore germination and hyphal growth of arbuscular mycorrhizal fungi. New Phytologist, 128, 103108.

http://dx.doi.org/10.1111/j.1469-8137.1994.tb03992.x

[128] Miranda, J.C.C. and Harris, P.J. (1994) The effect of soil phosphorus on the external mycelium growth of arbuscular mycorrhizal fungi during the early stages of mycorrhiza formation. Plant and Soil, 166, 271-280. http://dx.doi.org/10.1007/BF00008340

[129] George, E., Marschner, H. and Jakobsen, I. (1995) Role of arbuscular mycorrhizal fungi in uptake of phosphorus and nitrogen from soil. Critical Reviews in Biotechnology, 15, 257-270. http://dx.doi.org/10.3109/07388559509147412

[130] Howeler, R.H., Sieverding, E. and Saif, S. (1987) Practical aspects of mycorrhizal technology in some tropical crops and pastures. Plant and Soil, 100, 249-283. http://dx.doi.org/10.1007/BF02370945

[131] Amijee, F., Tinker, P.B. and Stribley, D.P. (1989) The 
development of endomycorrhizal root systems. VII. A detailed study of effects of soil phosphorus on colonization. New Phytologist, 111, 435-446.

http://dx.doi.org/10.1111/j.1469-8137.1989.tb00706.x

[132] Schroeder, M.S. and Janos, D.P. (2004) Phosphorus and intraspecific density alter plant responses to arbuscular mycorrhizas. Plant and Soil, 264, 335-348.

http://dx.doi.org/10.1023/B:PLSO.0000047765.28663.49

[133] Read, D.J. and Perez-Moreno, J. (2003) Mycorrhizas and nutrient cycling in ecosystems-A journey towards relevance? New Phytologist, 157, 475-492.

http://dx.doi.org/10.1046/j.1469-8137.2003.00704.x 